\title{
European integration, productivity growth and real convergence: Evidence from the new member states
}

\author{
Ali M. Kutan ${ }^{\mathrm{a}, \mathrm{b}, \mathrm{c}, \mathrm{d}}$, Taner M. Yigit ${ }^{\mathrm{e}, *}$ \\ ${ }^{a}$ Southern Illinois University, Edwardsville, United States \\ ${ }^{\mathrm{b}}$ The Center for European Integration Studies (ZEI), Bonn, Germany \\ ${ }^{\mathrm{c}}$ The Emerging Markets Group (EMG), London, United Kingdom \\ ${ }^{\mathrm{d}}$ The William Davidson Institute (WDI), Michigan, United States \\ ${ }^{\mathrm{e}}$ Bilkent University, Ankara, Turkey
}

\section{A R T I C L E I N F O}

\section{Article history:}

Received 19 January 2009

Received in revised form 22 March 2009

Accepted 25 March 2009

\section{JEL classification:}

P2

F15

01

J2

\section{Keywords:}

Productivity

Convergence

European Union

Transition economies

\begin{abstract}
A B S T R A C T
We estimate the determinants of labor productivity growth in 8 new European Union (EU) member states that joined the Union in 2004. Our focus is on the impact of globalization and EU integration efforts on labor productivity growth. Previous studies test the impact of trade using either exports or trade openness. We also test the impact of imports separately on labor productivity growth. Using panel data for 1995-2006 period, we find that globalization has mixed effects. FDI and exports improve productivity, but imports hurt it. Regarding domestic variables, we find that human capital is the most important source of labor productivity growth in the new member states. There is also considerable adjustment of labor productivity towards EU15 levels, indicating significant "catching up" and hence real convergence. Policy implications of the findings are also discussed.
\end{abstract}

(c) 2009 Elsevier B.V. All rights reserved.

\section{Introduction}

Following the breakdown of the former Soviet Union and its communist system in the early 1990s, the countries of Central and Eastern Europe (CEE) have gone through an unprecedented economic and political transformation. Following an initial and unexpected significant decline in economic activity, these countries have achieved significant economic growth starting in the mid- to late 90s. One of the

\footnotetext{
* Corresponding author.

E-mail address: tyigit@bilkent.edu.tr (T.M. Yigit).
} 
interesting features of this growth pattern has been the significant increase in labor productivity. According to the World Bank, during 1999-2004, the growth in labor productivity raised income per capita in CEE countries more than that in employment and population (World Bank Report, 2008). At the same time period, CEE labor productivity has grown at a rate greater than many other emerging and developing countries, including Russia and Ukraine (Rada and Taylor, 2006).

In this paper, we study two related issues for 8 CEE countries that joined the European Union (EU) in 2004, namely: the Czech Republic, Estonia, Hungary, Poland, Latvia, Lithuania, Slovakia and Slovenia. We will refer to these countries as the CEE8 in the rest of the paper. First, we investigate the determinants of labor productivity growth. Second, we test whether there have been some advances in labor productivity level towards that of core EU (i.e., EU15). Given the significant growth in their labor productivity, it is important for policymakers and other stakeholders to understand what factors have driven such growth. As the eventual goal of integration is the increase in standards of living to EU levels, further improvements in labor productivity play an instrumental role in satisfying such an economic (also historical and political) objective. This will facilitate the catching up (or real convergence) of CEE8 countries to the income levels of the core EU members. Evidence on such real convergence has important implications for the design of an optimal policy towards the entire euro zone. Within the new and candidate countries, significant progress toward per capita income convergence is seen as key in securing the political assent of the population to both transition and membership in the EU. For the EU countries, such income growth is important if excessive population movements from the new members to the old are to be avoided and if the EU's budget is not to be strained by transfers to lagging economies. In other words, real convergence has significant fiscal and monetary policy implications (Kutan and Yigit, 2007).

In a broader sense, the main objective of this paper is to better understand the implications of integration and globalization on labor productivity. We also account for the impact of domestic variables, namely, human capital, research development expenditures and domestic investment, which are all closely related to domestic policy-making. Given our objective, we believe that examining the case of CEE8 countries provides a unique study, as the integration efforts have been associated with significant internationalization activities as well. As former communist economies, they not only had to integrate their economies quickly with the West to survive the hardship of the former economic system, but also assumed the task of reaching the EU standards. The experience of these new EU members may provide important lessons for the candidate countries as well as other emerging economies.

Another important feature of our paper is that we test the individual effects of exports and imports on labor productivity separately. Recent literature has mainly focused on exports (Melitz, 2003; de Loecker, 2007) and FDI (Borensztein et al., 1998; Xu, 2000; Javorcik, 2004) to explain productivity changes. There are only a few available studies that investigate the direct impact of imports on productivity and the cross-country evidence on the issue is mixed (Blalock and Veloso, 2007; Kasahara and Rodrique, 2008). To our best knowledge, there is no aggregate country-level evidence regarding the import-labor productivity link for CEE8 countries. ${ }^{1}$

In the next section, we explain our theoretical framework. Section 3 further motivates the study by discussing the evolution of potential factors that might have affected the labor productivity growth in CEE8 countries. We also refer to some related studies that examine the determinants of labor productivity. In Section 3, we describe the data and discuss the estimation and the findings. The last section concludes with policy implications of the findings.

\section{Theoretical framework}

We borrow our theoretical framework from Bernard and Jones (1996a,b) and Cameron et al. (2005), who show that productivity growth of countries (or industries) is the result of domestic innovation or

\footnotetext{
${ }^{1}$ The only study that we have found is a recent unpublished work by Halpern et al. (2006), who employ a panel data of Hungarian firms to test the impact of imports on productivity. The paper argues that imports influence labor productivity through a quality and a variety channel and provides empirical evidence supporting that.
} 
technology transfers from frontier countries.

$$
\Delta \ln \left(A_{i t}\right)=\kappa_{i}+\gamma_{i} \ln \left(\frac{A_{F t}}{A_{i t}}\right)
$$

In Eq. (1), $A_{F t}$ and $A_{i t}$ represent the technical efficiency or productivity of the frontier and country $i$, respectively, while $\kappa_{i}$ is the country specific innovation and $\gamma_{i}$ is the rate of technology transfer from the frontier. We select EU15 countries as the relevant technological frontier for the CEE8 countries to specifically observe whether the size of the gap enhances the rate of technological spillovers to these recent new EU members from their more productive counterparts. As in Cameron et al., we assume that both $\kappa_{i}$ and $\gamma_{i}$ are time varying and determined by R\&D, international trade (imports) and human capital

$$
\kappa_{i t}=\beta_{1 i}+\delta Z_{i t-1} \quad \gamma_{i t}=\beta_{2 i}+\mu Z_{i t-1}
$$

where $Z_{i}$ is the vector of the above mentioned variables. ${ }^{2}$ While R\&D raises the rate of innovation, human capital proxies for absorptive capacity of technology, and finally, trade controls for the rate of technological transfer. In our study, we also include exports and FDI as other international channels of technological spillovers and domestic capital formation to account for the productivity impact of the varying utilization of physical capital over the business cycle.

Regarding R\&D expenditures as a driver of knowledge and innovation, Coe and Helpman (1995) find a significant link between productivity and R\&D capital stocks in EU countries. Engelbrecht (1997) extends Coe and Helpman's study by including a human capital variable to capture innovation, which may not be accounted by only R\&D capital stock. They find that, besides R\&D, human capital plays a unique role in affecting economic growth. Using data for several OECD countries, Griffith et al. (2004) confirm the importance of R\&D and human capital in the growth process. Their results also indicate that R\&D is important not only in innovation but also in technological catch-up.

FDI can improve labor productivity by serving as a supplement to domestic investment. Much of the FDI that came into transition economies has been used to purchase existing firms rather than to finance new Greenfield investments (Brada et al., 2006); however, even FDI used for mergers and acquisitions has a positive effect on domestic capital formation (Šohinger and Harrison, 2004) because investors do contribute additional capital to their acquisitions. Moreover, as Hunya (1996) shows in the case of Hungary, foreign firms have higher profits and reinvest a much higher share of it than do domestically owned firms, thus increasing capital formation in the future. Another benefit of FDI is that it brings in new technology and managerial skills (Brada et al., 2006). Thus, foreign-owned firms are likely to be more productive (Hunya, 1996; Sgard, 2001) and to use more advanced technologies (Voicu, 2004). Moreover, there are likely to be important spillovers of these technologies and managerial skills from foreign-owned firms to the domestic economy. ${ }^{3}$ Javorcik (2004) finds evidence for the existence of backward linkages between the downstream suppliers and the MNEs in Lithuania. Borensztein et al. (1998) and Xu (2000) argue that FDI's growth impact goes beyond its influence on total investment; it also depends on the stock of human capital in that country, suggesting that the benefits of higher FDI are realized not only through capital accumulation, but also through efficiency gains. All these factors associated with FDI are expected to improve the labor productivity in CES economies.

Melitz (2003) demonstrates that greater trade openness (especially exports) raises industry productivity via selection and production re-allocation effects. His model shows how trade will induce only the more productive firms to enter the export market and force the least productive firms to exit. He also emphasizes that the industry's exposure to trade will lead to inter-firm reallocations towards higher productivity. De Loecker (2007) finds further evidence for this idea using Slovenian manufacturing firms in his analysis of the changes in firm productivity when they start exporting. Controlling for the self-selection into export markets, he finds that export entrants become more

\footnotetext{
${ }^{2}$ The time period subscripts of the explanatory variables rely on their speed of transmission and will be discussed in the data section.

${ }^{3}$ Fan (2002) provides a useful survey of the literature on technology spillovers in transition economies. Aitken and Harrison (1999) and Blomstrom and Persson (1983) provide useful case studies.
} 
productive once they start exporting and that the productivity gap between exporters and their domestic counterparts increases further over time.

Theory also indicates that imports have a positive impact on labor productivity through technology spillovers. However, the empirical evidence on the impact of imports on productivity is scant and mixed. For example, Kasahara and Rodrique (2008), Blalock and Veloso (2007), Fernandes (2007) and Halpern et al. (2006) report positive effects of imports on productivity for plants or firms in Chile, Indonesia, Colombia, and Hungary, respectively. On the other hand, Keller and Yeaple (2003) find a negative impact for US multinationals and Muendler (2004) reports no impact on productivity for Brazilian plants. Overall, imports may have a positive or negative impact on productivity, depending upon (i) the composition of imports (i.e., high-tech or consumption goods), (ii) the relative cost of imports with respect to local substitutes and (iii) the relative usage of imported intermediaries in production with respect to domestic intermediaries (Kasahara and Rodrique, 2008, and Blalock and Veloso, 2007).

Besides country specific innovation variables $\left(\kappa_{i}\right)$ we discussed above, the theory outlined above also emphasizes the rate of technology transfer from the frontier $\left(\gamma_{i}\right)$ as a determinant of productivity growth.

Based on the discussion above, the testable equation becomes

$$
\Delta \ln \left(A_{i t}\right)=\beta_{1 i}+\delta Z_{i t-1}+\beta_{2 i} \ln \left(\frac{A_{F t}}{A_{i t}}\right)+\mu Z_{i t-1} \cdot \ln \left(\frac{A_{F t}}{A_{i t}}\right)+\varepsilon_{i t}
$$

Again $Z_{t}$ vector includes globalization variables (exports, imports, and FDI) and domestic innovation variables (human capital, domestic capital formation and $R \& D$ expenditures). The distance variable, a proxy for the rate of technology transfer from the frontier, is measured by the absolute value of the log ratio of productivity of country $i$ to the productivity of EU15. Hence, as the productivity gap between country $i$ and the frontier EU15 widens, this ratio grows smaller, making the absolute value of the log a larger number. With larger numbers, or a larger gap, the productivity growth of country $i$ is expected to be faster, indicating a positive coefficient. Our a priori expectations are toward finding a positive coefficient for all of the "innovation" variables in the model as well (with the possibility of a negative coefficient for imports).

\section{Evolution of labor productivity in CEE countries and globalization factors}

Fig. 1 shows EBRD data on labor productivity changes in industry for CEE8 countries. Although there have been periods of productivity slowdowns in early years in some countries due to events such as financial crises (i.e., the Czech Republic in 1997) and other country-specific events, the overall trend is positive. The biggest productivity increase took place in the three Baltic States. The net cumulative productivity change during 1995-2006 period was 108.6, 103.5, and 92.7 percent in Estonia, Lithuania and Latvia, respectively. Hungary and Poland are the next biggest productivity gainers in the region with a net cumulative gain of 74.6 and 67.8 percent, respectively. The other three CEE8 countries, Slovakia, the Czech Republic and Slovenia, had the lowest net cumulative productivity growth of 48.7,

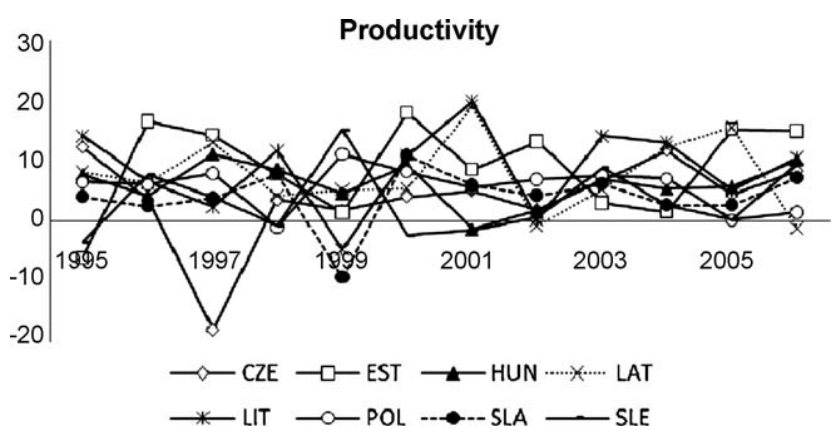

Fig. 1. Productivity changes (industry). 


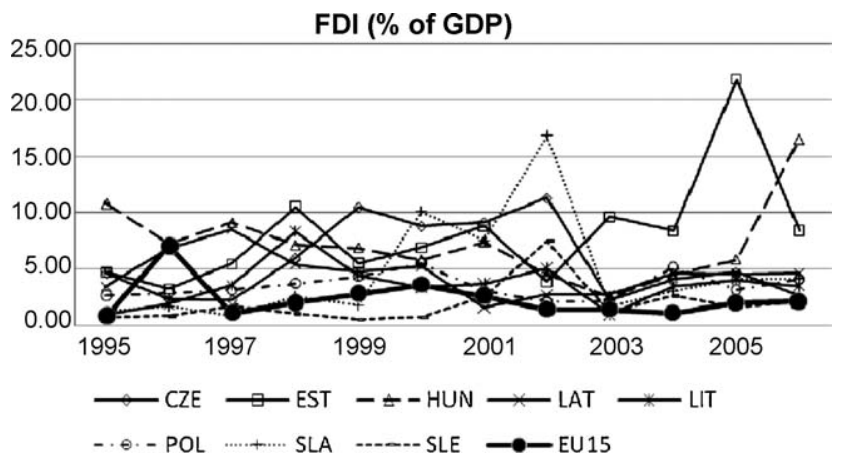

Fig. 2. FDI inflows to CEE8 countries.

44.6 and 40.4 percent, respectively. However, all the CEE8 countries outperformed the net cumulative productivity gains in EU 15, which was 24.2 percent during the same time period.

One of the most obvious reasons for growing labor productivity in the CEE8 countries is the significant amount of FDI flows (Fig. 2). Estonia, which has the biggest increase in her labor productivity, and Hungary, another significant productivity gainer, also received the highest average FDI flows with respect to GDP during our sample period, which was about 8.1 and 7.4 percent, respectively. Estonia's success is attributed to its potential market growth, the ease of access it affords to neighboring markets, the revision of FDI-related laws to create a transparent and nondiscriminatory legal regime, and an expansive privatization process (OECD, 2001). Unlike Estonia, Hungary was an early leader in FDI inflows, in part because of its more sophisticated economic relations with the West before the transition, which led many foreign investors to view Hungary as a country that had the infrastructure and economic savvy to accept foreign investments. Another reason for Hungary's early lead was its privatization strategy, which made sales of state-owned firms to foreign investors the preferred path to privatization (Brada et al., 2006). The Czech Republic attracted the next highest level of FDI inflows (5.71 percent of GDP), followed by Latvia and Slovakia (4.8 percent each). The remaining three CEE8 countries received relatively smaller level of average FDI inflows than the others during 1995-2006, namely, Lithuania (3.6 percent), Poland (3.5 percent) and Slovenia (1.9 percent). During the same period, EU15 countries received average level FDI inflows of about 2.3 percent of their respective GDP. The observation that those CEE8 countries with a relatively smaller share of FDI in GDP still exhibited large productivity gains suggests that there are other forces in play affecting labor productivity, such as international trade.

Figs. 3 and 4 show the evolution of exports and imports of CEE8 countries during 1995-2006. Although there was some volatility in the early 1990s, there has been a stable and upward trend in

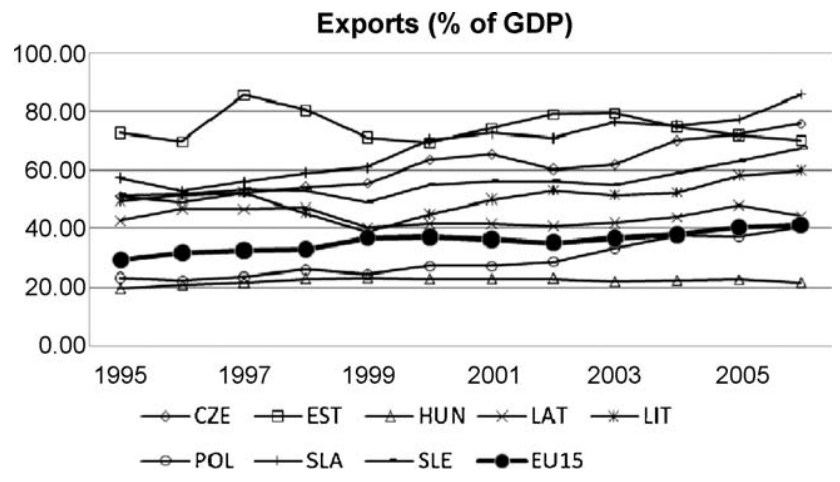

Fig. 3. CEE8 exports. 


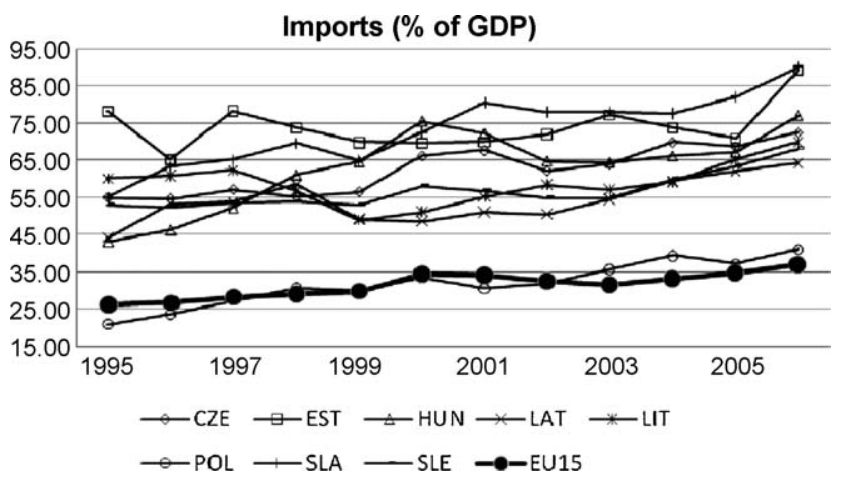

Fig. 4. CEE8 imports.

both exports and imports especially since 1999. In regards to exports, the Czech Republic, Poland, Slovakia and Slovenia have achieved the most significant growth in exports over time, reaching 70, 40, 85, and 67 percent of GDP in 2006, respectively. The corresponding export/GDP ratios in 1995 were 50, 23,57 , and 51 percent, respectively. Estonia, Hungary and Latvia did not have as much exports growth as these countries did, as their export ratios stayed relatively stable. On the imports side, we see a similar trend as well. In 1995, Poland had the smallest imports to GDP ratio (21 percent), but it increased significantly over time, reaching 41 percent in 2006. Estonia had the largest imports ratio of 78 percent in 1995 and reached almost 90 percent in 2006. Other countries also exhibited a large increase in imports over time. Overall, there was a significant growth in international trade flows during 1995-2006 period.

Fig. 5 shows the distance parameter as a measure of the rate of technology transfer from the frontier (EU15). The visible downward trend in all of the new member countries points toward the decline in the productivity gap and positive spillovers from the frontier to the less productive countries. Figs. 6-8 show the trends in our domestic innovation variables, namely, R\&D expenditures, education and capital formation, respectively.

\section{Methodology, data and results}

The sample period for the estimations is selected to be between 1995 and 2006. The productivity data is obtained from the "Transition Reports" of the EBRD (change in labor productivity of industry), while the rest of the data comes from AMECO of the European Commission's Directorate General for Economic and Financial Affairs and the EuroStat. The indicators are divided between domestic (R\&D

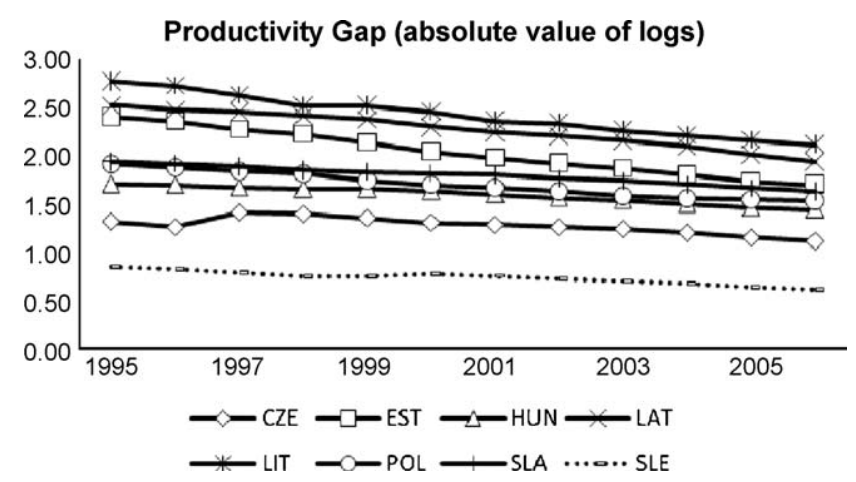

Fig. 5. Productivity gap between EU15 and CEE8 economies. 


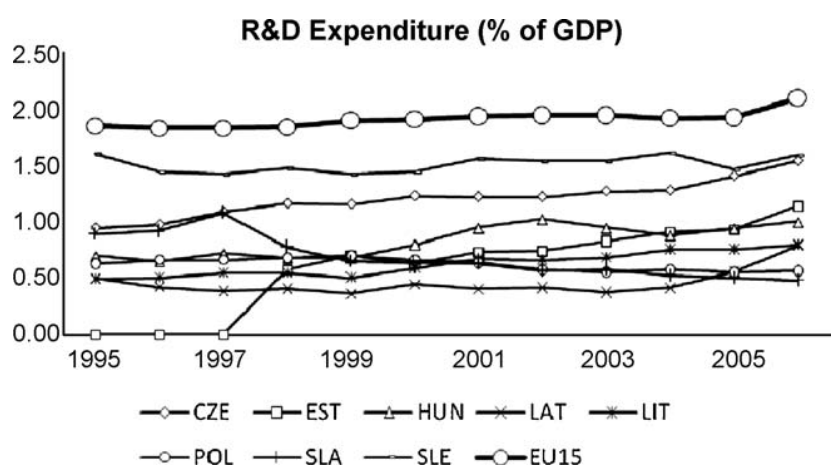

Fig. 6. Research and development expenditures.

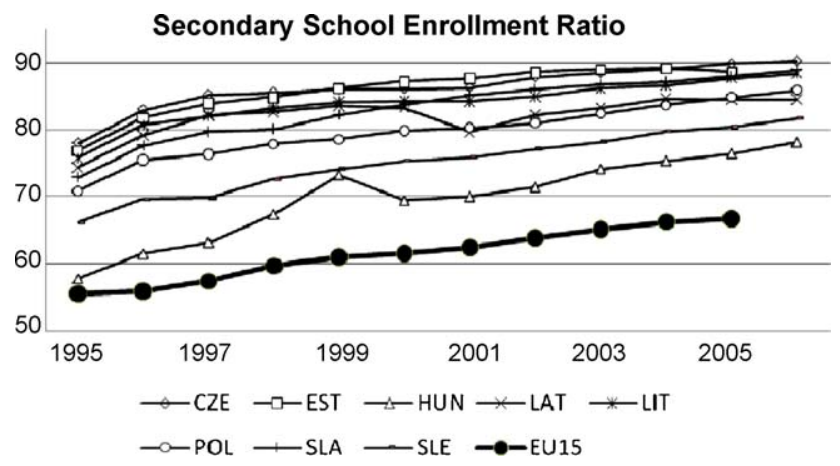

Fig. 7. Human capital.

expenditure, investment and secondary education) and international (productivity gap, imports, exports and FDI) variables. They are calculated as a percentage of GDP except for Education (\% of population) and for Productivity Gap (referred to as Distance in the regressions) as the absolute value of the $\log$ ratio of productivity of country $i$ to the productivity of EU15. Table 1 provides descriptive statistics.

The estimations are carried out using a fixed effects panel estimation correcting for potential heteroskedasticity in the cross sectional dimension. The time lag for the explanatory variables are

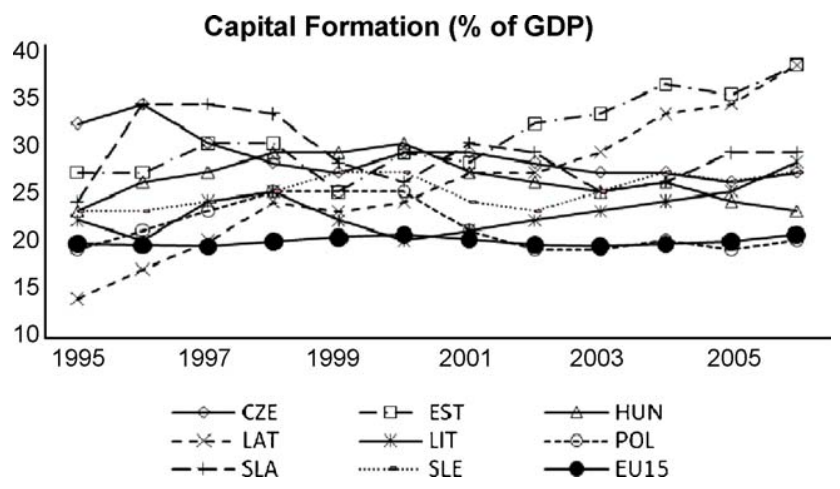

Fig. 8. Capital formation. 
Table 1

Descriptive statistics: mean (Variance).

\begin{tabular}{llllllll}
\hline & Prod. growth & Distance & R\&D & Education & Import & Export & FDI \\
\hline CZE & $3.7(59.2)$ & $1.28(0.01)$ & $1.2(0.03)$ & $86.3(11.5)$ & $62.6(43.4)$ & $60.8(78.0)$ & $5.7(11.3)$ \\
EST & $9.0(58.1)$ & $2.05(0.06)$ & $0.6(0.15)$ & $85.7(14.3)$ & $74.2(38.7)$ & $74.8(25.8)$ & $8.0(24.0)$ \\
HUN & $6.2(12.7)$ & $1.60(0.01)$ & $0.8(0.02)$ & $69.8(39.7)$ & $63.0(116.4)$ & $22.2(1.2)$ & $7.3(12.9)$ \\
LAT & $7.7(38.9)$ & $2.28(0.04)$ & $0.4(0.01)$ & $81.9(8.8)$ & $54.2(36.0)$ & $43.7(7.1)$ & $4.5(3.5)$ \\
LIT & $8.6(47.9)$ & $2.43(0.05)$ & $0.6(0.01)$ & $83.9(11.5)$ & $58.8(33.2)$ & $50.4(31.7)$ & $3.5(3.8)$ \\
POL & $5.6(12.6)$ & $1.71(0.02)$ & $0.6(0.00)$ & $79.6(18.2)$ & $31.9(36.6)$ & $29.1(39.5)$ & $3.4(1.1)$ \\
SLA & $4.0(23.9)$ & $1.81(0.01)$ & $0.7(0.04)$ & $83.1(23.1)$ & $73.3(96.6)$ & $67.8(107.4)$ & $4.5(22.2)$ \\
SLE & $3.3(32.8)$ & $0.74(0.01)$ & $1.5(0.01)$ & $74.9(23.1)$ & $57.0(23.8)$ & $55.7(27.3)$ & $1.9(3.5)$ \\
EU15 & & & $1.9(0.01)$ & $61.3(15.5)$ & $31.6(11.8)$ & $35.6(11.7)$ & $2.3(2.8)$ \\
\hline
\end{tabular}

Productivity growth refers to labor productivity at the industry level. Distance represents the last period's productivity gap of country $i$ (in absolute value of logs) to EU15. All variables except distance are measured in percentages (of GDP or of population).

chosen with respect to (i) the transmission period expected a priori ${ }^{4}$ and (ii) the larger contribution of the variables to the explanatory power of the model. Collinearity problems are fixed (when faced) by regressing the correlated variables on each other and using the residual of that regression. Examples for such corrections are the distance-R\&D pair and the interactive terms. The results are displayed in Table 2. Analyzing the descriptive statistics in Table 1 shows that the variation in the distance and R\&D variables are very small compared to other variables in the model. Consequently, we address the high level of correlation between the two variables $(\sim 0.9)$ by regressing distance on all other explanatory variables and using the auxiliary regression residual as the proxy for this variable. The first column in Table 2 shows the estimation of Eq. (3) without the interactive terms. The results show that the implications of our theory are mostly true. The rate of innovation in the CEE8 economies seems to be positively affected by the absorptive capacities (both domestic and international factors) of these economies.

Among the domestic factors, the R\&D expenditure of the CEE economies does not have any impact on productivity changes. However, secondary school enrollment ratio has a very significant effect on productivity changes, implying that higher education levels improve the environment for technological innovations. We also include fixed capital formation to account for the productivity impact of the varying utilization of physical capital over the business cycle. Although its coefficient seems to be insignificant, it contributes to the overall explanatory power very significantly, hence we opt to include it in our regressions. Its positive coefficient indicates that increases in the utilisation of physical capital over the business cycle lead to a rise in productivity.

The international factors in Table 2 also seem to play quite important roles as the determinants of productivity. Initially, the distance variable, i.e., the productivity gap, has a significant and positive sign, which implies that widening of the gap to the frontier leads to increases in productivity of the CEE countries. Second and as expected, the exports variable has a positive significant coefficient, validating the Melitz argument of increasing productivity through selection into the export market. However, imports seem to have a negative effect, likely due to a combination of high-cost of foreign intermediaries relative to domestic intermediaries, a relatively higher usage of the latter in domestic production and other relevant factors. FDI on the other hand has a significant and positive effect on productivity, confirming the claims of technological spillovers or labor force training.

The other columns add the interactive terms in the regression equation one by one. Again to resolve the problems of using the interactive term with its individual components (Ozer-Balli and Sorensen, 2008), we use the residuals from an auxiliary regression of the joint term on the individual parts. Both the signs and the explanatory power of the model show that these terms are not too relevant to increases in the industry productivity. The interactive term for R\&D especially is problematic (again probably due to low variation) and moves the R\&D parameter wildly, hence is kept out of the rest of

\footnotetext{
${ }^{4}$ Variables like education and imports are expected to have a lagging effect on technology while exports and FDI are expected to have synchronous effects. Hence, we use one lagged variables of imports, education and R\&D expenditures, and contemporaneous variables of exports, FDI and investment.
} 
Table 2

Productivity growth estimates.

\begin{tabular}{|c|c|c|c|c|c|c|c|}
\hline & (1) & (2) & (3) & (4) & (5) & (6) & (7) \\
\hline C & $\begin{array}{l}-54.05^{* *} \\
(-3.18)\end{array}$ & $\begin{array}{l}-53.11^{* *} \\
(-3.03)\end{array}$ & $\begin{array}{l}-53.81^{* *} \\
(-3.15)\end{array}$ & $\begin{array}{r}-51.44^{* *} \\
(-2.8)\end{array}$ & $\begin{array}{l}-62.68^{* *} \\
(-3.11)\end{array}$ & $\begin{array}{l}-61.81^{* *} \\
(-2.91)\end{array}$ & $\begin{array}{r}-55.43 \\
(-3.36)\end{array}$ \\
\hline Distance(-1) & $\begin{array}{l}9.69^{* *} \\
(2.04)\end{array}$ & $\begin{array}{l}9.15^{*} \\
(1.86)\end{array}$ & $\begin{array}{l}10.38^{*} \\
(1.88)\end{array}$ & $\begin{array}{l}9.98^{*} \\
(1.76)\end{array}$ & $\begin{array}{l}9.57^{*} \\
(1.68)\end{array}$ & $\begin{array}{l}9.47 \\
(1.64)\end{array}$ & $\begin{array}{l}8.62 \\
(1.84)\end{array}$ \\
\hline $\mathrm{R} \& \mathrm{D}(-1)$ & $\begin{array}{l}0.30 \\
(0.05)\end{array}$ & $\begin{array}{l}-1.22 \\
\quad(-0.2)\end{array}$ & $\begin{array}{r}0.45 \\
-0.08\end{array}$ & $\begin{array}{l}0.36 \\
(0.06)\end{array}$ & $\begin{array}{l}0.31 \\
(0.05)\end{array}$ & $\begin{array}{l}0.33 \\
(0.06)\end{array}$ & $\begin{array}{l}0.55 \\
(0.1)\end{array}$ \\
\hline Education(-1) & $\begin{array}{l}0.73^{* *} \\
(3.83)\end{array}$ & $\begin{array}{l}0.76^{* *} \\
(3.74)\end{array}$ & $\begin{array}{l}0.73^{* *} \\
(3.75)\end{array}$ & $\begin{array}{l}0.70^{* *} \\
(3.39)\end{array}$ & $\begin{array}{l}0.96^{* *} \\
(3.53)\end{array}$ & $\begin{array}{l}0.95^{* *} \\
(3.38)\end{array}$ & $\begin{array}{l}0.83 \\
(4.28)\end{array}$ \\
\hline Imports(-1) & $\begin{array}{l}-0.58^{* *} \\
\quad(-6.21)\end{array}$ & $\begin{array}{l}-0.57^{* *} \\
(-5.91)\end{array}$ & $\begin{array}{l}-0.58^{* *} \\
\quad(-6.20)\end{array}$ & $\begin{array}{l}-0.57^{* *} \\
(-6.12)\end{array}$ & $\begin{array}{l}-0.58^{* *} \\
(-5.91)\end{array}$ & $\begin{array}{l}-0.58^{* *} \\
(-5.60)\end{array}$ & $\begin{array}{l}-0.58 \\
\quad(-6.54)\end{array}$ \\
\hline Exports & $\begin{array}{l}0.50^{* *} \\
(3.55)\end{array}$ & $\begin{array}{l}0.47^{* *} \\
(3.08)\end{array}$ & $\begin{array}{l}0.51^{* *} \\
(3.30)\end{array}$ & $\begin{array}{l}0.51^{* *} \\
(3.21)\end{array}$ & $\begin{array}{l}0.40^{* *} \\
(2.39)\end{array}$ & $\begin{array}{l}0.40^{* *} \\
(2.37)\end{array}$ & $\begin{array}{l}0.43 \\
(2.93)\end{array}$ \\
\hline FDI & $\begin{array}{l}0.35^{* *} \\
(2.73)\end{array}$ & $\begin{array}{l}0.38^{* *} \\
(2.77)\end{array}$ & $\begin{array}{l}0.34^{* *} \\
(2.58)\end{array}$ & $\begin{array}{l}0.33^{* *} \\
(2.35)\end{array}$ & $\begin{array}{l}0.40^{* *} \\
(2.66)\end{array}$ & $\begin{array}{l}0.40^{* *} \\
(2.55)\end{array}$ & $\begin{array}{l}0.36 \\
(2.86)\end{array}$ \\
\hline Investment & $\begin{array}{l}0.25 \\
(1.34)\end{array}$ & $\begin{array}{l}0.23 \\
(1.19)\end{array}$ & $\begin{array}{l}0.24 \\
(1.20)\end{array}$ & $\begin{array}{l}0.24 \\
(1.19)\end{array}$ & $\begin{array}{l}0.09 \\
(0.39)\end{array}$ & $\begin{array}{l}0.08 \\
(0.37)\end{array}$ & $\begin{array}{l}0.16 \\
(0.79)\end{array}$ \\
\hline $\mathrm{D}^{*} \mathrm{RD}$ & & $\begin{array}{l}11.06 \\
(0.74)\end{array}$ & & & & & \\
\hline D*Education & & & $\begin{array}{l}0.14 \\
(0.26)\end{array}$ & $\begin{array}{l}0.13 \\
(0.23)\end{array}$ & $\begin{array}{l}0.04 \\
(0.08)\end{array}$ & $\begin{array}{l}0.05 \\
(0.09)\end{array}$ & \\
\hline D*Imports & & & & $\begin{array}{l}-0.09 \\
\quad(-0.36)\end{array}$ & $\begin{array}{l}0.29 \\
(0.86)\end{array}$ & $\begin{array}{l}0.28 \\
(0.80)\end{array}$ & \\
\hline D*Exports & & & & & $\begin{array}{l}-0.51 \\
\quad(-1.54)\end{array}$ & $\begin{array}{l}-0.51 \\
\quad(-1.49)\end{array}$ & $\begin{array}{l}-0.34 \\
\quad(-1.47)\end{array}$ \\
\hline D*FDI & & & & & & $\begin{array}{l}-0.08 \\
\quad(-0.12)\end{array}$ & \\
\hline Adj. $R^{2}$ & 0.411 & 0.389 & 0.406 & 0.397 & 0.382 & 0.389 & 0.444 \\
\hline$N$ & 78 & 78 & 78 & 78 & 78 & 78 & 78 \\
\hline
\end{tabular}

Note: $t$-statistics are reported inside the parentheses. Distance represents the last period's productivity gap of country $i$ (in absolute value of logs) to EU15. All variables except distance are measured in percentages (of GDP or of population).

the regressions. These results show that the technology transfer rate is not affected by domestic and international variables accounted for in our model. We need to be cautious in interpreting these results, especially with the interactive terms due to declining degrees of freedom and little variation in the distance variable.

We run robustness checks especially for endogeneity. ${ }^{5}$ For endogeneity, we run Wu (1973) test to find that when we use the contemporaneous values for the independent variables, we do not run into endogeneity problems. The second test we run is dynamic panel data estimation due to the possibility of industry growth being very closely related with the distance variable constructed by using output per labor. These tests also show that the standard errors of the coefficient estimates increase but their signs do not change.

\section{Conclusion, policy implications and suggestions for further research}

We have examined the role of innovation and the rate of technology transfer in explaining productivity at the industry level in eight Central and Eastern European countries that joined the

\footnotetext{
${ }^{5}$ Heteroskedasticity is addressed with the cross sectional weights, and autocorrelation tests are very unreliable due to the shortness of the data series.
} 
Union since 2004. Innovation variables are divided into global (FDI, exports and imports) and domestic (education, R\&D and investment) factors to determine whether globalization and integration factors have contributed to labor productivity more than domestic ones. Technology transfer rate is shown to be related to the distance in productivity levels between individual CEE8 countries and EU15 and is also used as a proxy for convergence in technical efficiency.

Regarding international innovation variables, we have found that all factors play a significant role in explaining labor productivity. However, FDI and exports are found to increase productivity growth, while imports reduce it. Given scant studies on the impact of imports on productivity and mixed available empirical evidence, our findings may shed some light on this highly debatable issue now. Our evidence is at the aggregate level and some policy can be deduced from aggregate impacts, but further research at the micro level is certainly necessary to better understand the imports-productivity link in CEE8 countries to help policymakers design policies accordingly.

Regarding domestic innovation variables, we found that education and investment variables are significant and positive, while R\&D is not. CEE8 countries have a highly educated and skilled labor force and our results show that this factor has been instrumental in improving productivity. Relatively small amount of R\&D expenditures (about 1-2 percent of GDP) in CEE8 countries may explain why this variable does not contribute much to labor productivity.

With respect to technological transfer, the evidence indicates a positive and statistically significant impact of distance from technological frontier on productivity growth, indicating significant technology transfer facilitating "catching up" by CEE8 countries towards EU15 productivity. However, our international and domestic variables do not seem to help facilitate this technology transfer. We attribute this unintuitive result to the relatively small number of observations we have.

Overall, our results suggest that globalization and integration factors affect labor productivity growth directly through rates of innovation, if not indirectly through distance from the technological frontier or technology transfer. An important policy implication of the results is that further policy attempts geared towards designing innovation-encouraging policies would have significant payoffs. Research at the micro level on the potential sources of the effects of imports on productivity would be useful. Our finding that variables typically used as determinants of productivity (such as R\&D, international trade, FDI) may not facilitate technology transfer suggests that there may be some informal channels present, such as the role of informal economy. Further research using longer samples and including more formal and some informal indicators of technological transfers from the frontier is necessary to generalize the findings of this study. We hope that our results provide some yardstick which can be used for comparison purposes.

\section{References}

Aitken, B.J., Harrison, A.E., 1999. Do domestic firms benefit from direct foreign investment? Evidence from Venezuela. American Economic Review 89 (3), 605-618.

Bernard, A., Jones, C., 1996a. Productivity across industries and countries: time series theory and evidence. Review of Economics and Statistics 78, 135-146.

Bernard, A., Jones, C., 1996b. Comparing apples to oranges: productivity convergence and measurement across industries and countries. American Economic Review 1, 216-238.

Blalock, G., Veloso, F.M., 2007. Imports, productivity and supply chain learning. World Development 35, 1134-1151.

Blomstrom, M., Persson, H., 1983. Foreign investment and spillover efficiency in an underdeveloped country: evidence from the Mexican manufacturing industry. World Development 11, 493-501.

Brada, J.C., Kutan, A.M., Yigit, T.M., 2006. The effects of transition and political instability on foreign direct investment inflows: Central Europe and the Balkans. Economics of Transition 14, 649-680.

Borensztein, E., De Gregorio, J., Lee, J.W., 1998. How does foreign direct investment affect economic growth? Journal of International Economics 45, 115-135.

Cameron, G., Proudman, J., Redding, S., 2005. Technological convergence, R\&D, trade and productivity growth. European Economic Review 49, 775-807.

Coe, D.T., Helpman, E., 1995. International R \& D spillovers. European Economic Review 39, 859-887.

de Loecker, J., 2007. Do exports generate higher productivity? Evidence from Slovenia. Journal of International Economics 73 , 69-98.

Engelbrecht, H., 1997. International R \& D spillovers, human capital and productivity in OECD economies: an empirical investigation. European Economic Review 41, 1479-1488.

Fan, E.X., 2002. Technological spillovers from foreign direct investment-a survey. Asian Development Bank ERD Working Paper 33, Manila. 
Fernandes, A.M., 2007. Trade policy, trade volumes, and plant-level productivity in Colombian manufacturers. Journal of International Economics 7, 52-71.

Griffith, R., Redding, S., Reenen, J.V., 2004. Mapping the two faces of R \& D: productivity growth in a panel of OECD industries. Review of Economics and Statistics 86, 883-895.

Halpern, L., Koren, M., Szeidl, A., 2006. Imports and Productivity. Federal Reserve Bank of New York, Mimeo, New York.

Hunya, G., 1996. Foreign Direct Investment in Hungary: A Key Element of Economic Modernization. The Vienna Institute for Comparative Economic Studies Research Report 226, Vienna.

Javorcik, B.S., 2004. Does foreign direct investment increase the productivity of domestic firms? In search of spillovers through backward linkages. American Economic Review 94, 605-627.

Kasahara, H., Rodrique, J., 2008. Does the use of imported intermediates increase productivity? Plant-level evidence. Journal of Development Economics 87 (1), 106-118.

Keller, W., Yeaple, S.R., 2003. Multinational enterprises, international trade, and productivity growth: firm level evidence from the United States. NBER Working Paper 9504, Cambridge, MA.

Kutan, A.M., Yigit, T.M., 2007. European integration, productivity and convergence. European Economic Review 51, $1370-1395$.

Melitz, M., 2003. The impact of trade on intra-industry reallocations and aggregate industry productivity. Econometrica 71 , $1695-1725$.

Muendler, M.A., 2004. Trade, technology and productivity: a study of Brazilian manufacturers 1986-1998. CESifo Working Paper 1148, Munich.

OECD, 2001. Review of foreign direct investment in Estonia. Available online at: http://www.investinestonia.com/pdf/OECDReviewFDIEstonia.pdf.

Ozer-Balli, H., Sorensen, B., 2008. The Use of Interaction Effects in Econometrics. University of Houston, Mimeo.

Rada, C., Taylor, L., 2006. Developing and transition economies in the late 20th century: diverging growth rates, economic structures, and sources of demand. The United Nations Department of Economic and Social Affairs (DESA) Working Paper 34, available at: http://www.un.org/esa/desa/papers/2006/wp34_2006.pdf.

Sgard, J., 2001. Direct foreign investments and productivity growth in Hungarian firms, 1992-1999. Centre d'Etudes Prospectives et d'Informations Internationales Working Paper 19, Paris.

Šohinger, J., Harrison, G.W., 2004. The implications of foreign direct investment for development in transition economies. Eastern European Economics 42, 56-74.

Voicu, I., 2004. Are foreign subsidiaries technologically superior to local firms? Evidence from Romania. Eastern European Economics 42, 5-32.

World Bank, 2008. Unleashing prosperity: Productivity growth in Eastern Europe and the former Soviet Union. Available at: http://go.worldbank.org/NS2LJ69070.

Wu, D., 1973. Alternative tests of independence between stochastic regressors and disturbances. Econometrica 41, 733-750.

$\mathrm{Xu}, \mathrm{B} ., 2000$. Multinational enterprises, technology diffusion, and host country productivity growth. Journal of Development Economics 62, 477-493. 